\title{
ANALISIS TERHADAP KEBIJAKAN DEMOSI PADA PEKERJA PT. MEGAH MITRA SUKSES (STUDI KASUS PUTUSAN NOMOR 146/PDT.SUS-PHI/2016/PN.JKT.PST JO PUTUSAN MAHKAMAH AGUNG NOMOR 257K/PDT.SUS-PHI/2017)
}

\author{
Kesuma Melati \\ (Mahasiswi Program S1 Fakultas Hukum Universitas Tarumanagara) \\ (E-mail: kesuma.melati19@yahoo.com)
}

\section{Dr. Stanislaus Atalim, S.H., M.H.}

(Corresponding Author)

(Dosen Fakultas Hukum Universitas Tarumanagara. Meraih Sarjana Hukum dari Fakultas Hukum Universitas Indonesia, Magister Hukum dari Fakultas Hukum Universitas Indonesia, Doktor Hukum dari Fakultas Hukum Universitas Parahyangan Bandung)

(Email: st_atalim@yahoo.com)

\begin{abstract}
Demotion occurs in a company mainly because of its negative influence on the morale of the workers concerned and can affect the achievement and morale of other workers in the company. Decline in the position of authority, facilities, status and even salary is a punishment for workers. Demosi is not given its arrangement in Law number 13 of 2003 concerning Manpower and other laws and regulations related to employment. Thus, this demotion arrangement can be regulated individually in work agreements, company regulations or collective labor agreements. The company does have the right to move workers in other parts but may not violate Human Rights and violate the provisions of Article 32 paragraph 2 of the Manpower Act which stipulates that placing someone who is not because of his expertise is against the law. Workforce placement must also pay attention to expertise, dignity and human rights and legal protection. The problem examined is how legal protection for workers due to demotion policy at PT. Magnificent Success Partner? And Is the legal consideration of the judge in the decision Number 146/Pdt.Sus-PHI/ 2016/PN.JKT.PST Jo Decision of the Supreme Court Number 257K/Pdt.Sus-PHI/2017 in accordance with the Manpower Act?Demotion will continue to occur if there are no strict rules regarding demotion, the government should make a regulation in the Labor Law regarding demotion, so that the rules regarding demotion become clear and do not harm the workers.
\end{abstract}

Keywords: Demotion, Human Rights, Legal Protection. 


\section{PENDAHULUAN}

\section{A. Latar Belakang}

Indonesia sebagai negara yang berkembang dengan jumlah penduduk yang banyak, sehingga membutuhkan lapangan pekerjaan seluas-luasnya untuk menyerap tenaga kerja. Arah pembangunan ketenagakerjaan telah jelas termuat di dalam Pasal 27 ayat (2) Undang-Undang Dasar 1945 yang menyatakan bahwa: "Setiap warga negara berhak atas pekerjaan dan penghidupan yang layak bagi kemanusiaan”. Sesuai dengan tujuan Negara Republik Indonesia sebagaimana yang tercantum dalam ketentuan Pasal 27 ayat (2) Undang-Undang Dasar 1945, hal tersebut menunjukkan bahwa menjadi tugas bersama untuk mengusahakan agar setiap orang yang mau dan mampu bekerja, mendapatkan pekerjaan yang sesuai dengan yang di inginkannya.

Bicara masalah bekerja tentu tidak terlepas akan istilah pekerja atau buruh, pekerja atau buruh adalah orang yang bekerja pada suatu perusahaan dan terikat dengan majikan perusahaan dalam suatu pekerjaan dan mendapat upah sesuai dengan ketentuan dan perjanjian. Sedangkan tenaga kerja adalah seseorang yang dapat melaksanakan pekerjaan yang kadang-kadang terikat maupun bebas. Perlu diketahui juga Hukum Perburuhan adalah himpunan peraturan-peraturan, baik tertulis maupun tidak tertulis yang berkenaan dengan kejadian dimana seseorang bekerja pada orang lain dengan menerima upah. ${ }^{1)}$

Setiap individu mempunyai keahliannya masing-masing yang dapat diandalkan untuk dijadikan pekerjaan atau profesi dalam memenuhi kebutuhan orang lain, sehingga dari profesinya tersebut memperoleh pendapatan berupa nilai jual yang secara ekonomis dapat menafkahi dirinya sendiri dan keluarganya. Pengusaha dalam memerintah buruh tidak boleh semena-mena, tetapi harus seirama dengan ketentuan perundang-undangan yang berlaku bahkan harus

\footnotetext{
1) Imam Soepomo, Pengantar Hukum Perburuhan, Cetakan ke-13, (Jakarta: Djambatan, 2003), hal. 2.
} 
sesuai dengan keadaan sarana-sarana pendukungnya. ${ }^{2)}$ Pengusaha juga dapat menempatkan buruh pada posisi-posisi yang telah diaturnya, namun hal ini harus disertai dengan kelayakan yang secara umum.

Mengelola sumber daya manusia, terkadang seorang manejer sumber daya manusia harus melakukan pemindahan pekerja atau buruh baik itu berupa promosi, mutasi, maupun demosi. Perubahan posisi atau jabatan atau tempat atau pekerjaan yang dilakukan baik secara horizontal maupun vertikal (promosi atau demosi) di dalam satu organisasi, bertujuan untuk memberikan feedback kepada pekerja atau buruh dalam upaya memperbaiki kinerja guna pencapaian peningkatan produktivitas organisasi perusahaan dengan cara melaksanakan berbagai program kebijaksanaan terhadap pekerja atau buruh seperti pendidikan dan pelatihan, pemberian promosi dan penjatuhan sanksi demosi. ${ }^{3}$ )

Demosi tidak diberikan pengaturannya Undang-undang Ketenagakerjaan maupun peraturan perundang-undangan lain terkait dengan ketenagakerjaan. Dengan demikian, pengaturan demosi ini dapat diatur sendiri di dalam perjanjian kerja, peraturan perusahaan atau perjanjian kerja bersama.

Perusahaan memang mempunyai hak untuk mengatur pembagian tugas kerja sesuai dengan kemampuannya dengan cara memindahkan karyawan dari suatu jenis pekerjaan atau tempat atau seksi atau bagian atau divisi, ke jenis pekerjaan atau tempat atau seksi atau bagian lain, tetapi seharusnya perusahaan tidak memindahkan pekerja secara sewenang-wenang yang menurunkan jabatan pekerja dari direktur HRD dijadikan atau ditempatkan sebagai Staff Steward yang mana di level staf itu tujuh jenjang turun sehingga demosi oleh perusahaan melanggar Hak Asasi Manusia (HAM) serta melanggar ketentuan Pasal 32 ayat 2 Undang-undang Ketenagakerjaan yang mana telah mengatur bahwa menempatkan

2) Y.W. Sunindhia, Masalah Pemutusan Hubungan Kerja dan Pemogokan, Cetakan ke-1, (Jakarta: Bina Aksara, 1988), hal. 163.

${ }^{3)}$ Marihot Tua Effendi Hariandja, Manajemen Sumber Daya Manusia, Pengadaan, Pengembangan, Pengkompensasian dan Pengikatan Produktivitas Karyawan, (Jakarta: Gramedia, 2002), hal. 26. 
seseorang yang bukan karena keahliannya bertentangan dengan hukum. Penempatan tenaga kerja harus pula memperhatikan keahlian, harkat dan martabat serta hak asasi dan perlindungan hukum.

Demosi akan terus terjadi jika tidak ada aturan yang tegas mengenai demosi, pemerintah seharusnya membuat suatu peraturan dalam Undang-undang Ketenagakerjaan mengenai demosi, sehingga aturan mengenai demosi menjadi jelas dan tidak merugikan pihak pekerja. Perusahaan tidak bisa semena-mena mendemosi pekerja atau buruh tanpa alasan yang jelas semata-mata untuk menghilangkan kewajibannya terhadap hak-hak pekerja atau buruh yang mana menggunakan alasan mengambil tindakan dalam rangka pembinaan pekerja untuk memindahkan pekerja atau buruh ke tempat lain dengan alasan perusahaan berhak mengatur pembagian tugas kerja sesuai dengan kemampuannya dengan cara memindahkan pekerja dari satu jenis pekerjaan atau tempat atau seksi atau bagian atau divisi ke jenis pekerjaan atau tempat atau seksi atau bagian atau divisi lain dalam jaringan Accor, yang mana penempatan tenaga kerja harus sesuai dengan keahliannya, keterampilannya, bakat, minat, dan kemampuan dengan memperhatikan harkat dan martabat serta hak asasi dan perlindungan hukum.

Tetapi nyatanya pengusaha tidak menempatkan pekerja sesuai dengan keahliannya, keterampilannya, bakat, minat, dan kemampuan serta tidak memperhatikan harkat dan martabat dan hak asasi serta perlindungan hukum yang tercantum dalam Pasal 32 Undang-undang Ketenagakerjaan, dan juga pengusaha memberikan alasan mutasi tersebut dengan alih-alih pembinaan pekerja yang mana pengusaha nyatanya tidaklah sesuai dengan maksud pembinaan yang tertuang di dalam Pasal 173 Undang-undang Ketenagakerjaan. Tindakan PT. Megah Mitra Sukses yang melakukan demosi secara sewenang-wenang terhadap pekerja tidak dapat dibenarkan oleh hukum, karena terbukti sebelum permintaan atas demosi itu dilakukan, PT. Megah Mitra Sukses telah mencoba mencari-cari kesalahan pekerja, dan General Manager memberikan tiga pilihan kepada pekerja 
yaitu diminta mengundurkan diri dan akan diberikan kompensasi 2 (dua) bulan gaji, ditransfer ke hotel lain yang dikelola oleh manajemen Accor, dan menempuh jalur hakum. Sehingga dari sini sudah tercerminkan adanya itikad tidak baik terhadap pekerja dan pihak PT. Megah Mitra Sukses memang sengaja mendemosi pekerja ke jenjang pekerjaan yang jauh dari jabatan pekerja sebelumnya yang mana jabatan Steward Staff tersebut tidaklah sesuai dengan keahliannya, keterampilannya, bakat, minat, dan kemampuan pekerja. PT. Megah Mitra Sukses juga tidak memberikan surat pindah ke hotel jaringan Accor dan melarang pekerja untuk mengabsensikan diri nya pada absen kerja di PT. Megah Mitra Sukses, yang mana hal ini dijadikan dasar bahwa pekerja dianggap mengundurkan diri tanpa pemberitahuan dan dalam pertimbangan hakim dikatakan bahwa pekerja telah melakukan tindakan indisipliner berupa pemecatan atau pemutusan hubungan kerja.

Berdasarkan hal-hal tersebut diatas, maka dilakukan penelitian dan menuangkan pada karya ilmiah dalam bentuk skripsi dengan judul "ANALISIS TERHADAP KEBIJAKAN DEMOSI PADA PEKERJA PT. MEGAH MITRA SUKSES (STUDI KASUS PUTUSAN NOMOR 146/PDT.SUSPHI/2016/PN.JKT.PST JO. PUTUSAN MAHKAMAH AGUNG NOMOR 257K/PDT.SUS-PHI/2017)"

\section{B. Permasalahan}

Berdasarkan uraian latar belakang di atas, maka penulis mengangkat permasalahan:

1. Bagaimana perlindungan hukum terhadap pekerja akibat kebijakan demosi pada PT. Megah Mitra Sukses?

2. Apakah pertimbangan hukum hakim dalam putusan Nomor 146/Pdt.SusPHI/2016/PN.JKT.PST Jo Putusan Mahkamah Agung Nomor 
257K/Pdt.Sus-PHI/2017 telah sesuai dengan Undang-Undang

Ketenagakerjaan?

\section{PEMBAHASAN}

\section{A. Perlindungan Hukum Terhadap Pekerja Akibat Kebijakan Demosi pada PT. Megah Mitra Sukses.}

Setiap orang berhak untuk bekerja serta mendapat imbalan dan perlakuan yang adil dan layak dalam hubungan kerja hal ini tertuang dalam Pasal 28 D ayat (2) UUD 1945. Berdasarkan pasal tersebut maka untuk menjaga keseimbangan dalam hubungan kerja antara pekerja dan pengusaha. Pemerintahan telah membuat peraturan-peraturan yang bertujuan melindungi pihak yang lemah yaitu pekerja. Sehingga hukum diciptakan sebagai suatu sarana atau instrumen untuk mengatur hak-hak dan kewajiban-kewajiban subyek hukum. Disamping itu, hukum juga berfungsi sebagai instrumen perlindungan bagi subyek hukum. Perlindungan hukum juga merupakan perlindungan akan harkat dan martabat, serta pengakuan terhadap hak-hak asasi manusia yang dimiliki oleh subyek hukum berdasarkan ketentuan hukum dari kesewenangan atau sebagai kumpulan peraturan atau kaidah yang akan dapat melindungi suatu hal dari hal lainnya. ${ }^{4)}$

Perlindungan terhadap tenaga kerja dimaksudkan untuk menjamin hak-hak dasar pekerja dan menjamin kesamaan kesempatan serta perlakuan tanpa diskriminasi atas dasar apapun untuk mewujudkan kesejahteraan pekerja. Salah satu bentuk perwujudan dari peningkatan harkat dan martabat bagi kalangan pekerja adalah perlindungan terhadap hak-hak pekerja baik yang diperjanjikan dalam Perjanjian Kerja maupun yang dituangkan dalam Peraturan Perusahaan atau Perjanjian Kerja Bersama.

\footnotetext{
${ }^{4}$ )Aloysius Uwiyono, Asas-asas Hukum Perburuhan. (Jakarta; Rajawali Pers, 2014), hal. 75
} 
Menurut Sudikno Mertokusumo, hukum berfungsi sebagai perlindungan kepentingan manusia, agar kepentingan manusia terlindungi maka hukum harus dilaksanakan. ${ }^{5)}$ Sedangkan Menurut Satjipto Raharjo, perlindungan hukum adalah memberikan pengayoman terhadap Hak Asasi Manusia (HAM) yang dirugikan orang lain dan perlindungan itu diberikan kepada masyakarat agar dapat menikmati semua hak-hak yang diberikan oleh hukum. Hukum dibutuhkan untuk mereka yang lemah dan belum kuat secara sosial, ekonomi, dan politik untuk memperoleh keadilan sosial. ${ }^{6)}$

Philipus M. Hadjon berpendapat bahwa ada dua bentuk perlindungan hukum bagi rakyat, yaitu perlindungan hukum preventif dan perlindungan hukum represif. ${ }^{7)}$ Perlindungan hukum preventif, yakni bentuk perlindungan hukum di mana subjek hukum diberi kesempatan untuk mengajukan keberatan atau pendapat sebelum suatu keputusan pemerintah mendapat bentuk yang definitif. Tujuannya adalah mencegah terjadinya sengketa. Perlindungan hukum preventif sangat besar artinya bagi tindak pemerintahan yang didasarkan pada kebebasan bertindak karena dengan adanya perlindungan hukum yang preventif pemerintah terdorong untuk bersifat hati-hati dalam mengambil keputusan yang didasarkan pada diskresi. Di Indonesia belum ada pengaturan khusus mengenai perlindungan hukum preventif. Perlindungan hukum represif, yakni bentuk perlindungan hukum di mana lebih ditujukan dalam penyelesaian sengketa.

Dalam pelaksanaan hak-hak normatif pekerja di Indonesia saat ini masih dikatakan jauh dari harapan atau dengan kata lain terdapat kesenjangan yang jauh antara suatu ketentuan normatif (law in books) dengan apa yang terjadi di lapangan (law in society/action) yang salah satu penyebabnya adalah belum

\footnotetext{
${ }^{5}$ Sudikno Mertokusumo. Mengenal Hukum. (Jakarta: Cahaya Atma, 2013), hal 145.

$\left.{ }^{6}\right)$ Satjipto Raharjo, Ilmu Hukum, (Bandung: PT. Citra Aditya Bakti, 2000), hal. 53.

${ }^{7)}$ Philipus M. Hadjon. Perlindungan Hukum Bagi Rakyat Indonesia, (Surabaya: Peradaban, 2007), hal.

2.
} 
maksimalnya pengawasan perburuhan atau ketenagakerjaan. Kenyataan yang terjadi di lapangan adalah pertama, pelaksanaan PKWT tidak sesuai dengan ketentuan Undang-undang Ketenagakerjaan, dengan melihat dari Perjanjian PKWT antara pekerja dengan perusahaan disitu tertulis bahwa pekerja di kontrak selama 2 (dua) tahun untuk masa jabatan sebagai direktur HRD, seperti tercantum pada Pasal 59 ayat (1) Undang-undang Ketenagakerjaan seharusnya pekerjaan yang diperjanjiakan tidak boleh menggunakan PKWT. Melihat sifat pekerjaan yang dilakukan oleh pekerja adalah pekerjaan yang bersifat tetap, terus menerus, bukan pekerjaan musiman, dan tidak selesai dalam waktu tertentu.

Mengenai kasus yang terjadi pada pekerja PT. Megah Mitra Sukses bahwa pekerja sebelumnya dikategorikan sebagai pekerja yang memiliki etos kerja yang baik sebelum terjadinya perselisihan antara perusahaan dan pekerja, pekerja dianggap telah melakukan 3 (tiga) kesalahan dengan itu perusahaan memberikan 3 (tiga) pilihan kepada pekerja yang mana pilihan tersebut tidak ada yang menguntungkan pekerja. Lalu pekerja pada proses mediasi dengan perusahaan yang disaksikan oleh mediator dari suku dinas tenaga kerja dan transmigarasi (Sudin nakertrans Jakarta Pusat) memberikan keterangan bahwa pada pertemuan tanggal 4 Februari 2016 pekerja menolak pilihan yang diminta oleh perusahaan yaitu pekerja diminta mengundurkan diri dan maka perusahaan akan memberikan kompensasi 2 (dua) bulan gaji, tetapi pekerja meminta pilihan dengan jalur hukum atau ditransfer ke hotel lain yang dikelola oleh Accor, lalu pihak perusahaan menyampaikan ada 2 (dua) hotel yang sedang mencari posisi HR yaitu Hotel Novotel Gajah Mada dan Hotel Mercure Jakarta Kota. Lalu salah satu pihak perusahaan memanggil pekerja keruang kerjanya dan menyampaikan bahwa pekerja akan diistirahatkan dari jabatan Direktur HRD mulai Jumat 5 Februari 2016, sehingga PHK dimulai dan hak pekerja akan dinegokan dengan General Manager dan Owner untuk dibayarkan sampai dengan akhir kontrak tanggal 31 Mei 2017. 
Bahwa pada tanggal 5 Februari 2016 pekerja sudah tidak diikutkan dalam morning briefing dan pekerja melaksanakan pekerjaan untuk persiapan hand-over sebagaimana diminta oleh perusahaan melalui salah satu pihak perusahaan, pada sore hari nya pekerja menerima undangan interview pada tanggal 10 Februari 2016 melalui email dari Cluster HR Manager Hotel Mercure Jakarta Kota Ibis Jakarta Harmoni. Lalu pada tanggl 6 Februari 2016 pekerja menerima telepon dari Director Of HR Accor yang mana ia mengatakan telah mengetahui persoalan antara pekerja dengan perusahaan dan akan membantu menjembatani untuk diakomodir di hotel lain yang dikelola oleh Accor. Pada tanggal 6 Februari 2016, manajemen menyerahkan surat demosi disertai surat SP II tetapi pekerja tidak dapat menerima tindakan perusahaan tersebut karena terkesan dipaksakan dan tergesa-gesa tanpa didukung bukti-bukti serta tidak prosedural.

Mengenai hasil dari penyelesaian secara bipartit tidak tercapai kesepakatan penyelesaian sehingga menghasilkan kesimpulan bahwa pihak perusahaan dan pekerja sudah tidak mempunyai rasa kecocokan antara satu sama lain, yang mana pihak perusahaan hanya menginginkan pekerja memilih 3 (tiga) pilihan yang telah dijabarkan sebelumnya. Dengan melihat keterangan dari pihak pekerja, bahwa menurut pekerja alasan demosi tersebut tidak kuat dan tidak prosedural serta bobot kesalahan yang ditimpakan kepada pekerja seharusnya perlu pembuktian dan klarifikasi. Apabila memang perusahaan tidak lagi menginginkan pekerja untuk bekerja pada perusahaan maka perusahaan seharusnya konsekuen untuk memenuhi kewajiban sebagaimana diamanatkan dalam Pasal 62 Undang-undang Ketenagakerjaan sehingga perusahaan dianggap telah memenuhi segala kewajibannya dan tidak melanggar hak asasi manusia pekerja.

Apabila melihat keterangan dari pihak perusahaan, bahwa yang menjadi dasar perusahaan melakukan demosi yaitu pada tanggal 26 Januari 2016, salah seorang pemilik perusahaaan datang untuk inspeksi dan ditemukan kantor atau ruangan pekerja tidak rapi dan kotor dan menegur keras pekerja yang bersangkutan karena 
pada saat itu ditemukan ada pekerja yang memakai celana pendek membawa tas ransel dan tidak rapi masuk ke area hotel serta ditemukan di loker pekerja helmhelm dan baju kotor yang digantung sehingga perusahaan menanyakan kapasibilitas dari pekerja sebagai Direktur HRD. Lalu mengenai kecelakaan yang menimpa mobil operasional kantor yang menurut keterangan perusahaan, yang mana security merupakan dibawah kontrol pekerja sebagai Direktur HRD tidak melakukan fungsinya dengan baik sehingga membuat pemilik hotel kecewa dan menegur keras pekerja. Atas kejadian tersebut, maka perusahaan memberikan surat SP II kepada pekerja dan pekerja merasa kecewa dengan keputusan pihak perusahaan. Pihak perusahaan melalui General Manager memberikan opsi 2 (dua) bulan gaji dan dibantu untuk transfer ke property Accor Hotel yang lain.

Pada tanggal 17 Februari 2016, diadakan pertemuan bipartit antara pekerja dengan pihak perusahaan dan perusahaan menawarkan lagi apakah pekerja mau dengan kompensasi yang perusahaan berikan sesuai dengan agreement awal, tetapi pekerja menolak dan tidak tercapai kesepakatan, apabila melihat bukti-bukti yang penulis miliki, perusahaan sering kali menawarkan pekerja atas kompensasi yang telah ditawarkan sebelumnya, apabila memang perusahaan ingin melakukan pembinaan terhadap pekerja dengan cara perusahaan mendemosi pekerja pada jabatan jauh dari jabatan awal pekerja, seharusnya perusahaan tidaklah perlu menanyakan mengenai kompensasi tersebut berulang-kali, karena terkesan perusahaan memang sebenarnya sudah tidak ingin pekerja bekerja pada perusahaan hanya saja perusahaan enggan untuk membayar uang sisa dari masa kontrak pekerja yang telah diperjanjikan sebelumnya.

Dengan melihat keterangan yang telah diberikan perusahaan maupun pekerja, untuk terpenuhinya perlindungan hukum bagi pihak pekerja maupun perusahaan maka mediator Suku Dinas Tenaga Kerja dan Transmigrasi Kota Administrasi Jakarta Pusat melalui proses mediasi antara perusahaan dengan pekerja maka pihak mediator mempunyai pendapat maupun pertimbangan hukum yang mana 
pihak mediator telah memanggil pekerja dan perusahaan secara patut dan layak untuk melakukan mediasi pada tanggal 15 Maret 2016 dan sidang mediasi 17 Maret 2016 untuk mencari solusi penyelesaian dengan prinsip musyawarah mufakat. Jika melihat dari tawaran perusahaan kepada pekerja dengan memberikan 3 (tiga) pilihan tersebut, pekerja lebih memilih point 3 yaitu di transfer ke hotel lain dan pekerja sempat memilih untuk dipindahkan kejaringan hotel lain dan berharap mendapat status yang sama. Tetapi, pada akhirnya pekerja tidak diberikan status yang sama tersebut tetapi diturunkan dengan posisi yang paling bawah dari struktur organisasi PT. Megah Mitra Sukses dengan alasan pembinaan pekerja, lalu pihak pekerja tetap masuk seperti biasa ke dalam perusahaan tetapi seperti yang tercantum pada Halaman 12 Putusan Mahkamah Agung bahwa pekerja tidak boleh masuk mengisi absensi karena larangan dari General Manager atas perintah Owner Hotel Grand Mercure. Tetapi pihak perusahaan mengatakan bahwa pekerja hanya masuk 7 (tujuh) hari kerja dalam 1 (satu) bulan yaitu bulan Mei 2016 dan pekerja sebagai pihak yang lemah kedudukannya sehingga tidak dapat membuktikan hal tersebut dan fakta persidangan tidak dijabarkan secara jelas ke dalam putusan. Lalu pada bulan April 2015 gaji dari penggugat sudah tidak lagi dibayarkan atas perintah dari Owner Hotel melalui General Manager. Jika memperhatikan Pasal 155 ayat (2) Undangundang Ketenagakerjaan jelas dikatakan bahwa selama putusan penyelesaian perselisihan hubungan industrial belum ditetapkan, baik pengusaha maupun pekerja harus tetap melaksanakan segala kewajibannya. Pihak pekerja telah berusaha melakukan kewajibannya dengan tetap datang ketempat kerja tetapi pihak perusahaan sudah tidak memberikan gaji pihak pekerja sejak bulan April 2015 yang mana proses pengadilan baru diputus pada bulan Oktober 2016. Karena tidak adanya upaya yang jelas dari pihak management, maka pekerja menempuh jalur hukum dengan melakukan pencatatan perselisihan hubungan industrial mengenai pemutusan hubungan kerja ke Sudin nakertrans Jakarta Pusat. 
Didalam hasil wawancara dengan Ilya Utama Sumono, S.H., beliau berpendapat bahwa demosi yang dengan alasan pembinaan pekerja ini yang terjadi kepada pekerja PT. Megah Mitra Sukses ini seharusnya tidak terjadi. Dengan melihat adanya penawaran dari pihak perusahaan dengan memberikan 3 (tiga) pilihan atas 3 (tiga) pelanggaran yang dilakukan oleh pekerja, apabila memang perusahaan ingin melakukan pembinaan, maka harus memperhatikan pembinaan yang tidak merugikan para pihak. Artinya dengan tetap memberikan gaji pokok dari pihak pekerja dan dengan tidak menurunkan jabatan pekerja ke jabatan yang jauh dibawahnya.

Menurut Pasal 173 Undang-undang Ketenagakerjaan, yang dimaksud dengan pembinaan adalah kegiatan yang dilakukan secara berdaya guna dan berhasil guna untuk memperoleh hasil yang lebih baik untuk meningkatkan dan mengembangkan semua kegiatan yang berhubungan dengan ketenagakerjaan. Jika melihat dari alasan perusahaan menurunkan jabatan pekerja dari direktur HRD menjadi Steward Staff tidaklah sesuai dengan pembinaan yang tercantum didalam Pasal 173 Undang-undang Ketenagakerjaan.

Pada kasus terjadinya demosi terhadap pekerja di PT. Megah Mitra Sukses yang memindahkan pekerja dari jabatan direktur HRD menjadi Steward Staff yang menempatkan posisi ketujuh atau yang paling bawah dari struktur organisasi PT. Megah Mitra Sukses dengan melihat adanya alasan yang dijabarkan oleh pihak perusahaan atas 3 (tiga) kesalahan pekerja, dengan mengutip dari pendapat Karolus Situmorang mengatakan bahwa demosi ini seharusnya tidak terjadi dengan melihat bahwa perusahaan mendalilkan pekerja telah melanggar Pasal 3.2 dan 3.3 Perjanjian Kerja Waktu Tertentu (PKWT) yang mana pekerja terikat dan berkewajiban untuk melaksanakan tugas pekerjaan yang telah disepakati dengan sebaik-baiknya sesuai dengan kecapakan dan kemampuannya untuk kepentingan pelaksanaan tugas pekerjaan dan untuk kepentingan perusahaan atau dalam rangka pembinaan pekerja atasan atau pimpinan perusahaan berhak mengatur 
pembagian tugas kerja sesuai dengan kemampuannya dengan cara memindahkan pekerja dari suatu jenis pekerjaan atau tempat atau seksi atau bagian atau divisi ke jenis pekerjaan atau tempat atau seksi atau bagian atau divisi lain ini. Apabila melihat dengan jelas bahwa di dalam Pasal 3.3 menggunakan kata-kata "pimpinan perusahaan berhak mengatur pembagian tugas kerja sesuai dengan kemampuannya" yang mana disini jenis pekerjaan baru yang diberikan pihak perusahaan kepada pekerja tidak lah sesuai dengan kemampuannya, yang mana sejak awal pekerja telah dikontrak dengan jabatan sebagai direktur HRD yang artinya bahwa perusahaan jelaslah tahu bahwa sejak awal kemampuan pekerja pada direktur HRD dan apabila memang perusahaan ingin menggunakan hak nya dalam hal mendemosi pekerja pihak perusahaan perlu memperhatikan bakat minat pekerja dan menempatkan pada posisi yang setara pada jabatan awal dengan tidak menurunkan gaji pokok pekerja atau bahkan tidak memberikan gaji pokok pekerja seperti yang sudah dilakukan oleh pihak perusahaan terhadap pekeja. Mengutip dari pendapat Sumantap M Simorangkir, S.H., M.H., bahwa seharusnya pekerja tidak di pindahkan ke jabatan terendah pada struktur organisasi perusahaan mengingat bahwa pekerja merupakan pekerja kontrak yang telah dikontrak 24 (dua puluh empat) bulan untuk menempatkan jabatan direktur HRD yang artinya bahwa perusahaan jelaslah tahu bahwa sejak awal kemampuan pekerja pada direktur HRD.

Sebagaimana diketahui, dalam Pasal 54 ayat (1) huruf c dan d Undangundang Ketenagakerjaan bahwa perjanjian kerja yang dibuat secara tertulis sekurang-kurangnya memuat antara lain jabatan atau jenis pekerjaan dan tempat pekerjaan. Dengan demikian, apabila salah satu pihak mengubah salah satu atau beberapa isi perjanjian kerja (termasuk mengubah jabatan pekerja atau jenis pekerjaannya, atau memindahkannya pada lokasi tempat kerja yang berbeda), maka tentu dapat dikategorikan telah menyalahi substansi perjanjian kerja secara sepihak. 
Walaupun demikian, bukan berarti perusahaan tidak dapat melakukan perubahan isi perjanjian kerja yang telah disepakati mengingat Pasal 55 Undang-undang Ketenagakerjaan jo. Pasal 1338 KUHPerdata bahwa perubahan substansi perjanjian kerja bisa saja diubah dengan ketentuan harus atas dasar persetujuan dan kesepakatan di antara para pihak. Bilamana perusahaan melakukan demosi tanpa adanya persetujuan pihak pekerja, maka menurut hemat penulis, kemungkinan yang bisa terjadi antara lain adalah bahwa pelaksanaan demosi dapat diartikan sebagai pengusaha telah memerintahkan pekerja untuk melaksanakan pekerjaan di luar yang diperjanjikan, dengan melihat Pasal 169 ayat (1) huruf e jo. Pasal 93 ayat (2) huruf f jo. Pasal 54 ayat (1) huruf c dan d Undang-undang Ketenagakerjaan pekerja hanya bersedia bekerja sesuai dengan isi perjanjian kerja.

Pada kasus ini, setelah pekerja dipanggil keruangan pihak General Manager pekerja tetap bekerja setelah diturunkannya jabatan pekerja dari direktur HRD ke Steward Staff, hal ini menunjukan bahwa pekerja telah mendedikasikan kinerjanya kepada perusahaan. Tetapi pekerja merasa tidak dapat bekerja dengan baik lagi kepada perusahaan selepas perselisihan antara pekerja dengan perusahaan karena tidak dapat mengaktualisasikan kemampuan dan kompetensi pekerja dengan maksimal.

Berdasarkan kasus demosi yang terjadi terhadap pekerja, untuk bentuk dari perlindungan pekerja tersebut maka seharusnya pekerja tetap mendapatkan gaji pokok dari sisa waktu yang telah diperjanjikan pada Perjanjian Kerja Waktu Tertentu (PKWT) yaitu 14 x Rp. 18.000.000,- = Rp. 252.000.000,- karena jika merujuk pada Pasal 155 ayat (2) Undang-undang Ketenagakerjaan dan apabila melihat dari keterangan-keterangan saksi yang dilampirkan di dalam putusan bahwa pekerja sempat datang beberapa kali ketempat kerja tetapi pekerja tidak melaksanakan pekerjaan nya dengan tuntas sebagaimana mestinya. Seharusnya pihak perusahaan jika memang mempunyai itikad baik agar pekerjanya tidak 
selalu melanggar aturan-aturan perusahaan sebaiknya perusahaan menegur pekerja dan tidak membiarkan pekerja untuk bekerja hanya dengan absen saja atau pekerja hanya masuk pada tanggal tertentu saja, bukan dengan membiarkan pekerja hanya absen pada tanggal-tanggal tertentu saja, dengan hal ini terlihat bahwa perusahaan membiarkan pekerja melakukan tindakan yang salah dan dengan hal ini pekerja tidak lagi mempunyai pembelaan akan hal kinerja dalam melaksanakan pekerjaannya. Sehingga dengan tidak mengisi absensi yang membuat pekerja dianggap mangkir.

Jadi, perlindungan hukum yang seharusnya pekerja dapatkan belum terpenuhi baik didalam Putusan Nomor 146/Pdt.Sus-PHI/2016/PN.JKT.PST maupun pada Putusan Mahkamah Agung Nomor 257K/Pdt.Sus-PHI/2017.

\section{B. Pertimbangan Hukum Hakim Dalam Putusan Nomor 146/Pdt.Sus- PHI/2016/PN.JKT.PST jo Putusan Mahkamah Agung Nomor 257 K/Pdt.Sus- PHI/2017 dengan Undang-Undang Ketenagakerjaan.}

Pengaturan mengenai demosi memang tidak diatur secara eksplisit maupun implisit didalam Undang-undang Ketenagakerjaan, tetapi hakim juga bisa membentuk hukum apabila ia melakukan penemuan kaidah hukum. Penemuan hukum ini lazimnya diartikan sebagai pembentukan hukum oleh hakim yang diberi tugas melaksanakan hukum terhadap peristiwa-peristiwa hukum yang konkrit. Hakim melakukan penemuan hukum adalah karena hakim tidak boleh menangguhkan atau menolak menjatuhkan putusan dengan alasan tidak adanya didalam suatu peraturan perundang-undangan. Analisis dasar pertimbangan hakim pada suatu putusan perkara adalah merupakan pekerjaan ilmiah seorang hakim, karena melalui pertimbangan hakim inilah hakim akan menerapkan hukum kedalam peristiwa konkrit dengan menggunakan logika hukum.

Hakim juga dapat melakukan suatu konstruksi hukum yang mana hal tersebut dapat dilakukan apabila suatu perkara yang dimajukan kepada hakim, tetapi tidak 
ada ketentuan yang dapat dijalankan untuk menyelesaikan perkara tersebut, meskipun telah dilakukan penafsiran hukum. Dalam hal demikian hakim harus memeriksa lagi sistem hukum yang menjadi dasar lembaga hukum yang bersangkutan. Apabila dalam beberapa ketentuan ada mengandung kesamaan, maka hakim membuat suatu pengertian hukum (rechtsbegrip) sesuai dengan pendapatnya.

Hakim memegang peranan penting dalam memberikan putusan, untuk dapat menyelesaikan suatu sengketa atau perkara, hakim harus mengetahui terlebih dahulu secara lengkap dan objektif tentang duduk perkara nya yang sebenarnya. Setelah suatu peristiwa dinyatakan terbukti, hakim harus menemukan hukum dan peristiwa yang disengketakan. ${ }^{8)}$

Bahwa pertimbangan hakim setelah membaca Perjanjian Kerja Waktu Tertentu (PKWT) antara pekerja dengan perusahaan khususnya ketentuan Pasal 13 Pemutusan Hubungan Kerja (bukti P-8 = T-1) yang secara khusus mengatur mengenai pengakhiran hubungan kerja atau pengakhiran Perjanjian Kerja Waktu Tertentu (PKWT) dengan segala implikasi hukumnya diperoleh fakta-fakta hukum sebagai berikut:

1. Perjanjian ini berakhir masa berlakunya sebagaimana tercantum dalam Pasal 2.1 Perjanjian ini;

2. Pekerja setuju dan menerima bahwa pekerja tidak berhak untuk memperoleh ganti kerugian apapun saat berakhirnya perjanjian ini atau pengakhiran yang sah oleh perusahaan sesuai dengan ketentuan dalam peraturan perundangundangan yang berlaku;

3. Hubungan kerja pekerja dapat diakhiri atau diputuskan pada setiap saat : (i) oleh pekerja tanpa alasan melalui pemberitahuan tertulis dari pekerja kepada pengusaha 30 hari sebelum atau (ii) oleh perusahaan tanpa alasan melalui pemberitahuaan tertulis dari perusahaan kepada pekerja 30 hari sebelumnya;

8).Yahya Harahap, Hukum Acara Perdata, Sinar Grafika, Jakarta: 2005, hlm. 798. 
4. Pekerja melakukan tindakan indisipliner yang dikenakan tindakan indisipliner berupa pemecatan atau Pemutusan Hubungan Kerja (PHK) dimaksud dengan alasan pelanggaran yang dikategorikan pelanggaran berat adalah tanpa uang pesagon dan tanpa uang penghargaan masa kerja;

5. Dalam hal pekerjaan yang ditugaskan kepada pekerja telah berkurang dimana perusahaan tidak memerlukan lagi jasa pekerja, maka perusahaan berhak memutuskan hubungan kerja dengan pekerja;

6. Pekerja terikat pada perusahaan dan wajib bekerja sampai dengan perjanjian ini berakhir. Jika pekerja mengundurkan diri sebelum berakhirnya perjanjian ini pekerja wajib memberitahukan perusahaan secara tertulis minimal 30 hari dimuka sebelum tanggal pengunduran diri;

7. Apabila pekerja dikualifikasikan mengundurkan diri karena mangkir selama 5 hari kerja atau lebih berturut-turut tanpa keterangan yang sah dan telah dipanggil oleh perusahaan 2 kali secara patut maka pekerja harus membayar kembali kepada perusahaann (a) upah bersih bulanan sebesar sisa masa kontrak (sampai dengan waktu kontrak berakhir), (b) seluruh biaya training (jika ada), termasuk biaya-biaya terkait;

8. Apabila hubungan kerja berkahir sebelum jatuh tempo hari raya keagamaan, pekerja tidak berhak menerima THR keagamaan, kecuali pekerja pindah atau di pindahkan ke hotel lain dalam grup Accor;

9. Pekerja meninggal dunia atau tidak mampu melakukan pekerjaan atau tugas kecuali sakit (hanya dibenarkan dengan adanya surat keterangan tertulis dari dokter) atau alasan yang sah lainnya;

Jika melihat point 4, jelas terjadi kekeliruan bahwa pekerja tidak melakukan kesalahan berat seperti yang dikategorikan didalam Pasal 158 ayat (1) Undangundang Ketenagakerjaan:

1. Pengusaha dapat memutuskan hubungan kerja terhadap pekerja dengan alasan pekerja telah melakukan kesalahan berat sebagai berikut: 
(a) melakukan penipuan, pencurian, atau penggelapan barang dan/atau uang milik perusahaan;

(b) memberikan keterangan palsu atau yang dipalsukan sehingga merugikan perusahaan;

(c) mabuk, meminum minuman keras yang memabukkan, memakai dan/atau mengedarkan narkotika, psikotropika, dan zat adiktif lainnya di lingkungan kerja;

(d) melakukan perbuatan asusila atau perjudian di lingkungan kerja;

(e) menyerang, menganiaya, mengancam, atau mengintimidasi teman sekerja atau pengusaha di lingkungan kerja;

(f) membujuk teman sekerja atau pengusaha untuk melakukan perbuatan yang bertentangan dengan peraturan perundang-undangan;

(g) dengan ceroboh atau sengaja merusak atau membiarkan dalam keadaan bahaya barang milik perusahaan yang menimbulkan kerugian bagi perusahaan;

(h) dengan ceroboh atau sengaja membiarkan teman sekerja atau pengusaha dalam keadaan bahaya di tempat kerja;

(i) membongkar atau membocorkan rahasia perusahaan yang seharusnya dirahasiakan kecuali untuk kepentingan negara; atau

(j) melakukan perbuatan lainnya di lingkungan perusahaan yang diancam pidana penjara 5 (lima) tahun atau lebih.

Juncto Putusan Mahkamah Konstitusi Nomor 115/PUU-VII/2009 tahun 2009

juncto Surat Edaran Menakertrans Nomor SE-13/MEN/SJ-HK/I/2005 jika pengusaha hendak melakukan PHK karena pekerja melakukan kesalahan berat, harus ada putusan hakim pidana yang berkekuatan hukum tetap terlebih dahulu.

Bahwa pertimbangan hakim setelah membaca Perjanjian Kerja Waktu Tertentu (PKWT) antara pekerja dengan perusahaan khususnya dalam Perjanjian Kerja Waktu Tertentu (PKWT) pada ketentuan Pasal 13 Pemutusan Hubungan Kerja, yang secara khusus mengatur mengenai pengakhiran hubungan kerja atau pengakhiran Perjanjian Kerja Waktu Tertentu (PKWT) dengan segala implikasi 
hukumnya diperoleh beberapa fakta-fakta hukum. Dengan melihat salah satu si dari point 5 yaitu : "dalam hal pekerjaan yang ditugaskan kepada pekerja telah berkurang dimana perusahaan tidak memerlukan lagi jasa pekerja, maka perusahaan berhak memutuskan kerja dengan pekerja”. Bahwa, terceminkan keberpihakan karena mengenai pekerjaan yang dijabati pekerja tersebut oleh pihak perusahaan tidak mengatakan bahwa pekerjaan yang ditugaskan kepada pekerja tersebut telah berkurang sehingga perusahaan tidak memerlukan jasa pekerja, sehingga disini pertimbangan hakim mencerminkan keberpihakan terhadap perusahaan. Sebagaimana yang tertuang didalam keputusan Mahkamah Agung Republik Indonesia Nomor KM A/104/A/SK/XII/2006 tentang pedoman perilaku hakim, hakim harus berperilaku adil, berperilaku jujur dengan tidak mencerminkan keberpihakan, berintegritas tinggi.

Putusan ini dirasa tidak memenuhi unsur filosofis yaitu keadilan, karena hakim memutuskan untuk menolak atas permohonan sisa masa kontrak pekerja. Pengambilan putusan dalam kasus ini, hakim dirasa tidak memperhatikan faktafakta hukum dalam persidangan yang mana pekerja dilarang untuk masuk kedalam area kerja dan tidak dapat melakukan absensi serta hakim juga tidak memperhatikan kesaksian yang ada pada persidangan yang mana para saksi telah mengatakan bahwa pekerja diturunkan jabatannya jauh dari posisi semula awal. Seharusnya hakim memberikan perlindungan hukum dalam hal mempertimbangkan mengenai sisa masa kontrak pekerja yang mana pekerja merupakan pihak yang lemah.

Putusan hakim pada kasus ini menurut penulis juga tidak memenuhi konsep pekerja. Dimana pekerja melakukan pekerjaan untuk mendapatkan imbalan yang mana imbalannya digunakan untuk memenuhi kebutuhan hidup dirinya, keluarganya atau masyarakat. Pekerja dianggap posisinya lebih lemah dari pengusaha, namun di depan hukum kedudukan antara perusahaan dengan pekeja sama. 
Di dalam pertimbangan hakim dikatakan, bahwa tindakan pekerja menolak demosi yang diberikan perusahaan dikarenakan menganggap kebijakan demosi tersebut tidak sesuai dengan kemampuan dan disiplin ilmu yang dipunyai pekerja adalah tidak wajar dan tidak dapat dipertimbangkan, mengingat mutasi atau promosi atau demosi adalah wewenang dan hak managemen yang tentunya berdasarkan aturan yang berlaku. Jika melihat Pasal 32 ayat (1) dan ayat (2) Undang-undang Ketenagakerjaan dikatakan bahwa:

a) Penempatan tenaga kerja dilaksanakan berdasarkan asas terbuka, bebas, obyektif, serta adil, dan setara tanpa diskriminasi.

b) Penempatan tenaga kerja diarahkan untuk menempatkan tenaga kerja pada jabatan yang tepat sesuai dengan keahlian, keterampilan, bakat, minat, dan kemampuan dengan memperhatikan harkat, martabat, hak asasi, dan perlindungan hukum.

Dalam memberikan pertimbangan hukum, hakim haruslah memperhatikan ketentuan-ketentuan yang berlaku, fakta-fakta persidangan serta hak-hak yang seharusnya pekerja dapatkan guna penegakan hukum yang mana hal tersebut merupakan wujud dari perlindungan hukum dari invidu yang disewenangwenangkan dengan individu lainnya. Oleh karena itu hakim haruslah memperhatikan kepastian hukum sebagai wujud perlindungan terhadap setiap individu agar tidak terjadi tindakan sewenang-wenang yang dilakukan oleh individu lainnya dan memperhatikan hakhak yang seharusnya diterima.

Seharusnya pihak perusahaan sebelum memutasi dan/atau mendemosi pekerja, hendaklah memperhatikan Pasal 32 ayat (1) dan ayat (2) Undang-undang Ketenagakerjaan bahwa berdasarkan asas terbuka, bebas, obyektif, serta adil, dan setara tanpa diskriminasi serta menempatkan tenaga kerja pada jabatan yang tepat sesuai dengan keahlian, keterampilan, bakat, minat, dan kemampuan dengan memperhatikan harkat, martabat, hak asasi, dan perlindungan hukum. Memang jelas bahwa mutasi maupun demosi merupakan kewenangan mutlak pihak 
perusahaan, tetapi perusahaan juga harus memperhatikan keahlian, keterampilan, bakat, minat, dan kemampuan pekerjanya. Karena pada kasus ini, jelaslah bakat minat pekerja pada bagian direktur HRD sehingga tidaklah wajar apabila pekerja diturunkan jabatannya ke jenjang pekerjaan yang paling bawah dari struktur organisasi PT. Megah Mitra Sukses. Pelaksanaan demosi dapat diartikan sebagai pengusaha telah memerintahkan pekerja untuk melaksanakan pekerjaan di luar yang diperjanjikan, dengan melihat Pasal 169 ayat (1) huruf e jo. Pasal 93 ayat (2) huruf f jo. Pasal 54 ayat (1) huruf c dan d Undang-undang Ketenagakerjaan pekerja hanya bersedia bekerja sesuai dengan isi perjanjian kerja. Namun dalam putusan Pengadilan Hubungan Industrial Nomor 146/Pdt.SusPHI/2016/PN.JKT.PST Jo Putusan Mahkamah Agung Nomor 257K/Pdt.SusPHI/2017 menurut penulis tidaklah memenuhi asas perlindungan hukum terhadap pekerja, yang mana hal ini dibuktikan dengan putusan hakim yang menolak atas tuntutan hak-hak yang diajukan oleh pekerja. Dalam hal pengambilan putusan tersebut bahwa hakim tidak memperhatikan fakta-fakta hukum dalam persidangan dan tidak tepat dalam menerapkan dasar serta terlihat adanya keberpihakan oleh hakim kepada perusahaan, yang mana seharusnya hakim memberikan putusan yang seadil-adilnya bagi para pihak sehingga hal ini tidaklah belum terpenuhinya dengan apa yang seharusnya yang tercantum pada Undang-undang Ketenagakerjaan.

\section{PENUTUP}

\section{A. Kesimpulan}

Berdasarkan paparan analisis diatas berkaitan dengan penelitian yang telah dilakukan, maka penulis dapat menarik kesimpulan yaitu:

1. Demosi yang dilakukan terkesan bentuk akal-akalan dari perusahaan untuk mem-PHK pekerjanya (faktor like or dislike). Apabila memang 
perusahaan ingin mendemosi pekerja terlebih alasan pembinaan karyawan seharusnya pekerja tidak perlu diberikan 3 (tiga) pilihan sebelum akhirnya perusahaan mendemosinya, karena disini terkesan pihak pekerja sudah tidak lagi dibutuhkan oleh pihak perusahaan. Agar menghindar dari pembayaran sisa konrak, perusahaan mendalilkan bahwa ini merupakan pembinaan karyawan, yang mana apabila pekerja ditempatkan pada posisi terendah maka ada kemungkinan pekerja akan merasa tidak betah dan akan mengundurkan dirinya dari perusahaan, sehingga hal tersebut tidaklah perlu bagi perusahaan untuk membayar sisa dari masa kontrak kerja pekerja.

Dengan melihat keterangan yang telah diberikan perusahaan maupun pekerja, untuk terpenuhinya perlindungan hukum bagi pihak pekerja maupun perusahaan maka mediator Suku Dinas Tenaga Kerja dan Transmigrasi Kota Administrasi Jakarta Pusat melalui proses mediasi antara perusahaan dengan pekerja maka pihak mediator mempunyai pendapat bahwa pekerja tetap mendapatkan hak nya berupa sisa masa kontrak yang telah diperjanjikan sebelumnya yang mana sisa masa kontraknya yaitu 14 (empat belas bulan) x 18.000.000,- (Delapan Belas Juta Rupiah) tetapi perusahaan menolak, dan hakim juga memutuskan bahwa pekerja tidak berhak untuk mendapatkan hak-hak apapun. Sehingga menurut penulis, dengan tidak diberikannya hak-hak tersebut maka belum terpenuhinya perlindungan hukum terhadap pekerja.

2. Pertimbangan hakim terhadap putusan ini tidaklah memenuhi asas perlindungan hukum terhadap pekerja, yang mana hal ini dibuktikan dengan putusan hakim yang menolak atas tuntutan hak-hak yang diajukan oleh pekerja secara seluruhnya. Dalam hal pengambilan putusan tersebut bahwa hakim tidak memperhatikan fakta-fakta hukum dalam persidangan dan tidak tepat dalam menerapkan dasar serta terlihat adanya 
keberpihakan oleh hakim kepada perusahaan, yang mana seharusnya hakim memberikan putusan yang seadil-adilnya bagi para pihak sehingga hal ini tidaklah belum terpenuhinya dengan apa yang seharusnya yang tercantum pada Undang-undang Ketenagakerjaan.

\section{B. Saran}

1. Bagi pihak perusahaan, agar mengusahakan tidak terjadinya demosi yang terkesan akal-akalan seperti ini, juga sebaliknya bagi pekerja yang tidak menerima untuk di demosi harus memberikan penjelasan yang jelas kepada pihak perusahaan yang mana hal tersebut dapat dijadikan pertimbangan bagi pihak perusahaan sehingga tidak dapat dijadikan alasan bagi pihak perusahaan untuk kemudian mem-PHK pekerjanya dengan alasan menolak perintah kerja, terlebih jika tidak tercapai kesepakatan antara kedua belah pihak. Mengenai demosi juga harus diberikan pengaturan secara jelas dan khusus yang tercantum dalam Peraturan Perusahaan, Perjanjian Kerja, serta Perjanjian Kerja Bersama agar memiliki prosedur yang jelas dan dasar hukum yang mengikat.

2. Bagi pihak pekerja, apabila memang pekerja menerima demosi tersebut lakukanlah tugas pekerja dengan sebaik mungkin sehingga apabila pekerja ingin menggugat perusahaan, tidak ada celah bagi pihak lain untuk menyalahkan pekerja, karena pekerja telah melakukan pekerjaan dengan sebaik mungkin. Lalu pekerja kedepannya harus lebih memperhatikan lagi dengan baik Peraturan Perusahaan, Perjanjian Kerja, dan Perjanjian Kerja Bersama yang berlaku dalam perusahaan serta peraturan perundangundangan yang lain terkait dengan bidang ketenagakerjaan. Dengan maksud apabila terjadi suatu perselisihan antara pekerja dan perusahaan khususnya pemutusan hubungan kerja berkaitan dengan demosi, pekerja 
dapat mengetahui dengan baik masing-masing hak dan kewajiban pengusaha maupun pekerja.

3. Bagi pihak pemerintah, perlu adanya perubahan terhadap Undang-undnag Ketenagakerjaan saat ini, karena dengan berkembangnya suatu teknologi maka pekerja semakin tidak diperlukan lagi dengan begitu pekerja sebagai pihak yang lemah kedudukannya tidak ada perlindungan hukum yang cukup memenuhi hak-hak pekerja dan untuk demosi sendiri juga tidak diatur secara eksplisit maupun implisit pada Undang-undang Ketenagakerjaan yang mana mengenai demosi merupakan hal yang sering ditemukan pada lapangan.

\section{DAFTAR PUSTAKA}

\section{A. Buku}

Effendi Hariandja, Marihot Tua. Manajemen Sumber Daya Manusia, Pengadaan, Pengembangan, Pengkompensasian dan Pengikatan Produktivitas Karyawan. Jakarta: Gramedia, 2002.

Harahap, Yahya. Hukum Acara Perdata. Jakarta: Sinar Grafika, 1987.

Mertokusumo, Sudikno. Mengenal Hukum Liberty Yogyakarta. Yogyakarta: Djembatan, 1999.

M. Hadjon, Philipus. Perlindungan Hukum Bagi Rakyat Indonesia. Surabaya: Peradan, 2007.

Raharjo, Satjipto. Hukum Ilmu Hukum. Bandung: PT. Citra Aditya Bakti, 2000.

Soepomo, Imam. Pengantar Hukum Perburuhan. Jakarta: Djembatan, 1999.

Sunindhia, YW. Masalah Pemutusan Hubungan Kerja dan Pemogokan. Cetakan ke-1. Jakarta: Bina Aksara, 1988.

Uwiyono, Aloysius. Asas-asas Hukum Perburuhan. Jakarta: Rajawali Pers, 2014. 
Kesuma Melati \& Stanislaus Atalim Analisis Terhadap Kebijakan Demosi Pada Pekerja PT. Megah Mitra Sukses (Studi Kasus Putusan Nomor 146/Pdt.Sus-PHI/2016/PN.JKT.PST Jo

Putusan Mahkamah Agung Nomor 257K/Pdt.Sus-PHI/2017)

\section{B. Artikel Jurnal Online}

Husna, Dinal Dkk. "Prestasi Kerja, Kondisi Organisasi, Perilaku Disfungsional dan Demosi Pns". Jurnal Kebijakan Publik. Volume 3, Nomor 2 Tahun 2012: 3

Pratitha,Yasmin Chairunisa Muchtar. "Pengaruh Penerapan Promosi Dan Demosi Terhadap Prestasi Kerja Karyawan Pada Master Kredit Cabang Medan". Jurnal USU. Volume 1, Nomor 1 Tahun 2013: 3 